\title{
Polyphasic Approaches to Lactobacilli Identification: Comparison of Phenotypic, Genotypic and Spectroscopic Methods
}

\author{
Aisha, M. El Attar ${ }^{1}$, Tourkya², B., Françoise Leriche² \& El Soda M. ${ }^{1}$ \\ ${ }^{1}$ Dairy Science and Technology Dept., Fac. of Agric. Alexandria Univ., Alexandria, Egypt \\ 2 UR Consommateur Aliment Typique Sécurité Santé, VetAgro Sup - Campus Agronomique de \\ Clermont, 89 avenue de l'Europe BP 35, 63370 Lempdes, France
}

\begin{abstract}
Lactobacillus forms a large and diverse group of lactic acid bacteria (LAB). In raw milk and dairy products such as cheeses, yoghurts and fermented milks, lactobacilli are either naturally present or added intentionally for technological reasons or to generate a health benefit for the consumer. The Lactobacillus taxonomy has continued to evolve over the last twenty years, and currently consists of over 170 species.

We employed API 50CH (Apparatus and Procedure of Identification) and SDS-PAGE (sodium dodecyl sulfate--polyacrylamide gel electrophoresis) as phenotypic techniques to establish the identity of 52 wild lactobacilli isolated from artisanal dairy products. The identifications were confirmed using repetitive genomic element-PCR (Rep-PCR) fingerprinting and spectral methods including fluorescence spectroscopy. The SDS-PAGE results confirmed about $90 \%$ of API identification results. PCR using Boxair primers discriminated tested strains into Lactobacillus delbrueckii subsp. bulgaricus, Lactobacillus delbrueckii subsp. lactis, Lactobacillus fermentum, Lactobacillus paracasei subsp. paracasei, and Lactobacillus plantarum. This genetic method confirmed all the SDS-PAGE phenotyping results. Synchronous fluorescence spectra (SyFS) were recorded from 31 non-transparent bacterial colonies using a FluoroMax-2 spectrofluorometer linked to an optic fiber, and the results confirmed all the genotypic results, excluding certain strains: Lb. plantarum $(217 \mathrm{~N}$ and $1025 \mathrm{RM})$ and $L$ b. paracasei subsp. paracasei $286 \mathrm{KC}$ as identified by the fluorescence method were genetically reclassified as $L b$. delbrueckii subsp. lactis and Lb. plantarum, respectively.

Our study therefore highlights that spectral data provide real phenotypic fingerprints of the bacteria and can thus be used for taxonomic purposes. This study found that BOXPCR is a good tool for confirming most of the phenotypic identifications, making it possible to taxonomically characterize and differentiate wild-type lactic acid bacteria isolated from traditional dairy products.
\end{abstract}

Key words: Lactobacillus sp, artisanal dairy products, API 50CH, SDS-PAGE, Rep-PCR, intrinsic fluorescence spectroscopy.

\section{INTRODUCTION}

Among lactic acid bacteria, the genus Lactobacillus, whose classification is constantly being reshuffled, today encompasses more than 171 species and 27 subspecies (www.bacterio.cict.fr). It forms a diverse and heterogenic group of strictlyfermentative Gram-positive bacteria which exhibit remarkable adaptability to diverse habitats including vegetation, mucosal membranes, and the gastrointestinal tracts of terrestrial and marine animals. Domestication of lactobacilli for milk preservation originates in the Ptolemaic period of ancient Egypt (Allen, 1936). Today, various species are used worldwide as main or supplementary ingre- dients in commercial preparations for manufacturing fermented products. Indeed, lactobacilli have well-documented probiotic effects in humans and animals and their use has been rapidly extended to the animal feed and self-care health industries. The European Food Safety Authority (EFSA) proposed the qualified presumption of safety (QPS) concept to provide a generic risk assessment approach for biological agents authorized for use in the food and feed chain, and 35 lactobacillus species currently appear on the approval positive list (EFSA, 2010). The introduction of new isolates and basic studies both hinge on reliable taxonomic positioning of the isolates among other safety criteria. For taxonomic 
purposes, polyphasic approaches are recommended (Vandamme, 1996), combining phenotypic and genotypic data collection (Bernardeau et al., 2008).

Phenotypic identification of Lactobacillus at species level mainly uses microscopic descriptors, biochemical trait descriptions. Other biomarkers can complete the analysis (Montel et al., 1991), although these methods have their limitations due to relatively poor reproducibility, and ambiguous identification of closely-related species (Wijtzes et al., 1997), they can now be supplemented with a large range of genotyping analyses (Tailliez et al., 2002, Coeuret et al., 2003, Naser et al., 2007). Among them, species-specific PCR is able to discriminate closely-related species (i.e. Lb. plantarum and $L b$. para plantarum ) that $16 \mathrm{~S}$ and 23SRNA sequencing fail to discriminate (Berthier and Ehrlich, 1998, Delfederico et al., 2006). However, these methods are time-consuming and expensive to implement.

Alternative tools based on vibrational spectroscopy are in development, and are gaining increasing interest. Among them, Raman and Fourier transform (FT)-infrared spectroscopy (Amiel et al., 2000, Mariey et al., 2001), have been effectively applied for lactic acid bacteria discrimination at species level (Bosch et al., 2006, Gaus et al., 2006, Dziuba et al., 2007, Savi et al., 2008). Other techniques such as mass spectrometry and related methodologies including pyrolysis-mass spectrometry, gas chromatography/mass spectrometry, matrix-assisted laser desorption/ionization-time of flight (MALDI-TOF) have also been successfully used (Sauer \& Kliem, 2010) but are relatively laborious, involving sample preparation steps and reagent inputs (Bosch et al., 2006, Postnikova et al., 2008). Nevertheless, in the spectroscopy field, fluorescence spectroscopy does offer inherent advantages compared to FT-infrared, such as no signal noise from water, high sensitivity, and short collection-time requirements (Estes et al., 2003). In taxonomic applications, this method relies on the fact that bacteria retain several intrinsic fluorophores which emit photons according to excitation in the UV region. Tryptophan, phenylalanine and tyrosine are some of the most commonly-used fluorescent molecules. The nucleotides could also fluoresce, but their quantum yields are about 100 times lower than with tryptophan (Cantor \& Schimmel, 1980, Lakowicz, 1999). Since the middle of the last decade, several authors have demonstrated that fluorescence spectra collected from bacterial cells could be considered fingerprints of the bacteria, thus discriminating microorganisms belonging to different taxonomical families (Leblanc \& Dufour, 2002, Leriche, 2004, Bhatta et al., 2006) or bacteria at family, genus, species, and subspecies level (Ammor, 2007). This paper describes the use of phenotyping, molecular methods and fluorescence spectroscopy to discriminate and identify Lactobacillus strains isolated from traditional Egyptian dairy products at genus, species and subspecies levels.

\section{MATERIALS AND METHODS}

\section{Bacterial strains and cultivation}

Fifty-two cultures were isolated from 20 samples of raw milk, Zabady (Egyptian fermented milk), Kareish cheese and French cheeses. All isolates were identified to genus level according to Sharpe (1979) using morphological, phenotypic and biochemical methods. Cultures of these isolates were stored at $-80^{\circ} \mathrm{C}$ in reconstituted skimmed milk supplemented with $15 \%(\mathrm{v} / \mathrm{v})$ of glycerol for storage. Working cultures were prepared from frozen stocks through two transfers in MRS broth.

\section{Phenotypic methods}

In addition to preliminary tests, carbohydrate fermentation profiles were evaluated using the API 50CH system (bioMérieux, Marcy-l'Étoile, France) following the manufacturer's instructions. Fermentation profiles were interpreted using the APILAB Plus V.3.2.2 computer-aided database.

For SDS-PAGE analysis of the whole-cell proteins, preparation of cell extracts and polyacrylamide gel electrophoresis were done according to Pot et al. (1994). Gel-Compar software (Applied Maths, Sint-Martens-Latem, Belgium, V. 4.0) was utilized to compare the protein patterns of the isolates against the intern reference database built from reference strains from the Laboratory of Microbial Biochemistry (LMB, ROM and ES) at the Faculty of Agriculture, Alexandria University, Egypt and the Centre National de Recherche Zootechnique Jouyen-Josas, France (CNRZ). These reference strains were $\mathrm{Lb}$. del. bulgaricus ES0036, Lb. del. lactis CNRZ245, Lb. fermentum 9LMB, Lb. paracasei paracasei $2 \mathrm{ROM}$, and $L$ b. plantarum CNRZ739.

Hierarchical agglomerative clustering of isolates was performed using the Pearson's product moment correlation coefficient (r) and the un- 
weighted pair group method using average linkage (UPGMA), as described by Pot et al. (1994).

\section{Genotypic identification method DNA Extraction}

Total DNA was extracted from $1.6 \mathrm{ml}$ of fresh cultures in the exponential phase using the Wizard DNA purification Kit following the manufacturer's instructions (Promega, Madison, WI., USA).The DNA concentration was assessed by determining O.D at 260 and $280 \mathrm{~nm}$ using an Ultrospectro 3000 system (Amersham Biosciences, Sweden).

\section{Rep-PCR genomic fingerprinting}

The DNA concentration of each sample was adjusted to $25 \mathrm{ng} / \mu 1$ in a $25 \mu 1$ PCR mixture. Amplification was performed in a $25 \mu \mathrm{l}$ reaction volume typically containing $20 \mathrm{ng}$ genomic DNA, $0.3 \mu \mathrm{M}$ Boxair primers (5'-CXTAXCGGCAAGGCGACGCTGACG-3') and puReTaq Ready-ToGo PCR beads (Amersham Biosciences, Sweden).

The PCR program was 35 thermal denaturation cycles for $30 \mathrm{sec}$ at $92^{\circ} \mathrm{C}$, annealing for $1 \mathrm{~min}$ at $40^{\circ} \mathrm{C}$ and extension for $2 \mathrm{~min}$ at $72^{\circ} \mathrm{C}$. The cycles were preceded by denaturation at $92^{\circ} \mathrm{C}$ for 2 min and followed by extension at $72^{\circ} \mathrm{C}$ for $5 \mathrm{~min}$ The PCR products were separated by electrophoresis at $50 \mathrm{~V}$ on a $2 \%(\mathrm{w} / \mathrm{v})$ agarose (Amersham Biosciences. Sweden), and DNA was detected by UV transillumination after staining with ethidium bromide $(10 \mathrm{mg} / \mathrm{ml})$. The molecular sizes of the amplified DNA fragments were estimated by comparison with a 100 bp DNA ladder (Promega, Madison, Wiscon. USA). Conversion, normalization and further analysis of Rep-PCR patterns were carried out using Gel Compar V.4.0 software (Applied Maths, Kortrijk, Belgium). Similarity coefficients for pairs of tracks were calculated using Pearson's product moment correlation coefficient (r). Strains were grouped by UPGMA. Reference strains were obtained from the different $\mathrm{LAB}$ culture collections in the reference databases cited earlier.

\section{Optic-fiber based synchronous fluorescence spectroscopy}

\section{Measurements}

Synchronous fluorescence spectra (SyFS) were recorded from the bacterial colonies using a FluoroMax-2 spectrofluorometer (Spex-Jobin Yvon, Longjumeau, France) linked to an optic fiber. The optic fiber was set at $9 \mathrm{~mm}$ above the colonies to keep the light beam diameter at less than $2 \mathrm{~mm}$. SyFS collected in the excitation wavelength range was 250-500 nm (resolution: $1 \mathrm{~nm}$, slits $18 \mathrm{~nm}$ ), excitation wavelength $\lambda_{\text {ex }}$, and emission wavelength $\lambda_{\text {em }}$ were scanned synchronously with a fixed offset $\Delta \lambda$ of $=30 \mathrm{~nm}$. For each strain, three SyFS spectra were acquired for three independent colonies resulting from culturing on MRS agar plates at 30 or $37^{\circ} \mathrm{C}$ for $48 \mathrm{~h}$ depending on the growth conditions of each microorganism. As fluorescence spectroscopy is not suitable for characterizing transparent colonies, the opaque colonies of Lactobacillus cultures were only tested.

Thirty one wild strains of lactobacillus were studied (5 Lb. delbrueckii subsp. lactis, $4 \mathrm{Lb}$. delbrueckii subsp. bulgaricus, 16 Lb. plantarum, 4 Lb. paracasei subsp. paracasei and 2 Lb. fermentum.). The reference strains were $L b$. delbrueckii subsp. lactis CIP101028T (Collection de l'Institut Pasteur Paris), Lb. delbrueckii subsp. bulgaricus CIP101027T (Collection de l'Institut Pasteur Paris), Lb. plantarum ATCC14917 ATCC (American Type Culture Collection) and Lb. paracasei subsp. paracasei ATCC11978 (American Type Culture Collection).

\section{Spectral data analysis}

The data were analyzed using XLStat-pro software (Addinsoft, Paris, France) and Statistica software build 6.1 (Statsoft, Maisons-Alfort, France). In order to minimize scattering effects, all fluorescence spectra were normalized by reducing the area under each spectrum to a value of 1 according to Bertrand \& Scotter (1992).

Factorial discriminant analysis (FDA) was chosen as the most appropriate multivariate analysis tool for emphasizing differences between experimental groups (Wittrup, 2000). Before running the FDA analysis, information contained in the spectra was first compressed using principal component analysis (PCA) as described by Jolliffe (1986). The PCA allows the variables (wavelengths) to be transformed into new orthogonal variables called principal components (Bertrand et al., 2006), while conserving an overview of all the information in the dataset. The PCA was computed from the variance/ covariance matrices. The first 10 PCs contained more than $99.9 \%$ of the information in the spectral datasets, and were used to perform FDA to discriminate the lactobacilli strains at different levels. For each analysis, the data were introduced into predefined groups or classes (one class was one taxo- 
nomic cluster, species, or subspecies) according to the taxonomic level chosen for discrimination level between strains. For example, for discrimination of reference strains at species level, three groups were created ( $L b$. delbruecki, Lb plantarum, Lb paracasei), while for discrimination of all tested strains, five groups were created ( $L b$. delbrueckii subsp. lactis, Lb. delbrueckii subsp. bulgaricus, Lb. plantarum, Lb. paracasei subsp. paracase $i$ and $L b$. fermentum). The validation step used leave-oneout cross-validation (LOOCV), where a single observation from the original sample is used as the validation data and the remaining observations as training data. Repetitions ensure that each observation in the sample is used once as validation data (Kohavi, 1995).

\section{RESULTS AND DISCUSSION}

\section{Phenotypic methods}

Looking at galerie API LAB results, 41 of the 52 strains analyzed were satisfactorily identified. Doubts remains over the identification of 11 strains, as shown in Table (1).

These results further support numerous authors who have questioned the reliability of the commercial tests for the identification of lactobacilli at the species and subspecies levels (Sanchez et al., 2004, Boyd et al., 2005).

The results from numerical analysis of SDSPAGE whole-cell protein patterns were coherent with the API results for about $90 \%$ of the isolates. The few discrepancies concerned isolates classified as Lactobacillus delbrueckii subsp. bulgaricus and Lactobacilus. delbrueckii subsp. Lactis using SDSPAGE but as Lactobacilus salivarius $(497 \mathrm{~N})$ and Lactobacilus acidophilus (137FR), respectively, using the API system. Similar results have been observed by El Soda et al. (2003) and Mohammed et al. (2009).

\section{Strain typing using Rep-PCR}

Rep-PCR fingerprinting patterns generated from Boxair primer amplification were able to differentiate the 52 isolates initially assigned to the Lactobacillus genus on the basis of phenotypic methods. Nine strains were identified as $L b$. delbrueckii subsp. bulgaricus, 18 strains were Lb. delbrueckii subsp. lactis, 3 strains were Lb.fermentum, 4 strains were $L b$. paracasei subsp. paracasei, and 18 strains were $L b$. plantarum. The amplification profiles indicated that $L b$. delbrueckii subsp. lactis shared two common bands around 0.3 and $1 \mathrm{~Kb}$, Lb. delbrueckii subsp. bulgaricus had three common bands around $0.3,1$ and $2 \mathrm{~Kb}, L$ b. paracasei subsp. paracasei gave bands in the range of 0.3$0.8 \mathrm{~Kb}, \mathrm{Lb}$. fermentum gave three intense bands around $0.7,0.4$ and $0.3 \mathrm{~Kb}$, while $L$ b. plantarum exhibited four intense bands around 0.3, 0.6, 0.8 and $1 \mathrm{~Kb}$ and faint bands around 0.9 and $1.5 \mathrm{~Kb}$. These results confirm the observations of Mohammed et al. (2009).

According to UPGMA analysis, the strains were grouped into 5 clusters at a similarity level of about 20\%, as shown in Figure (1). Cluster A grouped the type strains of $L b$. delbrueckii subsp. bulgaricus with $80 \%$ similarity, Cluster B grouped the type strains of Lb. delbrueckii subsp. lactis with $85 \%$ similarity, Cluster C grouped the type strains of Lb. fermentum with $65 \%$ similarity, Cluster D grouped the type strains of $L b$. paracasei subsp. paracase $i$ with $70 \%$ similarity, and $L b$. plantarum strains were grouped into two main clusters (Clusters I and II respectively) with $65 \%$ similarity.

Analysis of the DNA fingerprints generated by the BOX primer allowed a reliable grouping of the wild-type Lactobacillus isolates at species or subspecies level. Characteristic amplification patterns were obtained from strains of $L b$. delbrueckii subsp. bulgaricus, Lb. delbrueckii subsp. lactis, Lb. fermentum, Lb. paracasei subsp. paracasei and $L b$. plantarum. For all 52 isolates, taxonomic positioning was consistent with SDS-PAGE results (Table 1).

\section{Intrinsic fluorescence spectra of tested strains}

As described previously (Ammor 2007, Tourkya et al., 2009), spectra shapes varied substantially through LAB and could be considered as real fingerprints of each bacteria, allowing an in-depth comparison of strain profiles

A first step led to verify the discrimination of the reference strains. Spectral data collected from Lb. delbrueckii subsp. bulgaricus, Lb. delbrueckii subsp. lactis, Lb. plantarum and Lb. paracasei subsp. paracasei were pooled in one matrix and analyzed by PCA. Before applying FDA, groups were created as described in the materials and methods section. On the factorial map (not shown) corresponding to FDA performed on synchronous spectra, the first two discriminant factors (F1 and 
Table 1: Identification of Lactobacillus isolates using phenotypic, genotypic and spectroscopic methods.

\begin{tabular}{|c|c|c|c|c|}
\hline Strain & $\begin{array}{c}\text { Strains identified by } \\
\text { API }\end{array}$ & $\begin{array}{c}\text { Strains identified by } \\
\text { SDS-PAGE }\end{array}$ & $\begin{array}{c}\text { Strains identified by } \\
\text { rep-PCR }\end{array}$ & $\begin{array}{l}\text { Strains identified by } \\
\text { spectroscopic method }\end{array}$ \\
\hline $610 \mathrm{~N}$ & $\begin{array}{l}\text { Lb. del. bulgaricus } \\
\text { Lb. helveticus }\end{array}$ & Lb. del. bulgaricus & Lb. del. bulgaricus & N.T. \\
\hline $572 \mathrm{~N}$ & $\begin{array}{l}\text { Lb.del. lactis } \\
\text { Lb. del. bulgaricus } \\
\text { Lb.helveticus }\end{array}$ & $\begin{array}{l}\text { Lactobacillus del. } \\
\text { bulgaricus }\end{array}$ & Lb. del. bulgaricus & Lb. delbrueckii \\
\hline $702 \mathrm{~N}$ & $\begin{array}{l}\text { Lb. del. bulgaricus } \\
\text { Lb.helveticus }\end{array}$ & Lb. del. bulgaricus & Lb. del. bulgaricus & N.T. \\
\hline $722 \mathrm{~N}$ & $\begin{array}{l}\text { Lb. del. bulgaricus } \\
\text { Lb. helveticus }\end{array}$ & Lb. del. bulgaricus & Lb. del. bulgaricus & N.T. \\
\hline $726 \mathrm{~N}$ & $\begin{array}{l}\text { Lb. del. bulgaricus } \\
\text { Lb.helveticus }\end{array}$ & Lb. del. bulgaricus & Lb. del. bulgaricus & N.T. \\
\hline $725 \mathrm{~N}$ & $\begin{array}{l}\text { Lb. del. bulgaricus } \\
\text { Lb.helveticus }\end{array}$ & Lb. del. bulgaricus & Lb. del. bulgaricus & Lb.delbrueckii \\
\hline $497 \mathrm{~N}$ & Lb.salivarius & Lb. del. bulgaricus & Lb.del. bulgaricus & N.T. \\
\hline $635 \mathrm{~N}$ & $\begin{array}{l}\text { Lb.del. bulgaricus } \\
\text { Lb.helveticus } \\
\text { Lb. del. delbrueckii } \\
\text { Lb. del. lactis }\end{array}$ & Lb.del. bulgaricus & Lb.del. bulgaricus & Lb.delbrueckii \\
\hline 722RM & $\begin{array}{l}\text { Lb.del. lactis } \\
\text { Lb.helveticus } \\
\text { Lb.del. bulgaricus }\end{array}$ & Lb.del. bulgaricus & Lb.del. bulgaricus & Lb.delbrueckii \\
\hline $157 \mathrm{FR}$ & $\begin{array}{l}\text { Lb.del. lactis } \\
\text { Lb.acidophilus }\end{array}$ & Lb.del. lactis & Lb.del. lactis & N.T. \\
\hline 153FR & $\begin{array}{l}\text { Lb.del. lactis } \\
\text { Lb.acidophilus }\end{array}$ & Lb.del. lactis & Lb.del. lactis & N.T. \\
\hline $178 \mathrm{~N}$ & Lb.del. lactis & Lb.del. lactis & Lb.del. lactis & Lb.delbrueckii \\
\hline 697RM & $\begin{array}{l}\text { Lb.del. lactis } \\
\text { Lb.acidophilus }\end{array}$ & Lb.del. lactis & Lb.del. lactis & N.T. \\
\hline $712 \mathrm{~N}$ & $\begin{array}{l}\text { Lb.helveticus } \\
\text { Lb.del. bulgaricus } \\
\text { Lb.del. lactis }\end{array}$ & Lb.del. lactis & Lb.del. lactis & Lb.delbrueckii \\
\hline 164FR & $\begin{array}{l}\text { Lb.del. lactis } \\
\text { Lb.acidophilus }\end{array}$ & Lb.del. lactis & Lb.del. lactis & N.T. \\
\hline $162 \mathrm{FR}$ & $\begin{array}{l}\text { Lb.del. lactis } \\
\text { Lb.acidophilus }\end{array}$ & Lb.del. lactis & Lb.del. lactis & N.T. \\
\hline $217 \mathrm{~N}$ & $\begin{array}{l}\text { Lb.helveticus } \\
\text { Lb.del. bulgaricus } \\
\text { Lb.del. lactis }\end{array}$ & Lb.del. lactis & Lb.del. lactis & Lb.plantarum \\
\hline $156 \mathrm{FR}$ & $\begin{array}{l}\text { Lb.del. lactis } \\
\text { Lb.acidophilus }\end{array}$ & Lb.del. lactis & Lb.del. lactis & N.T. \\
\hline 223FR & $\begin{array}{l}\text { Lb.del. delbrueckii } \\
\text { Lb.acidophilus }\end{array}$ & Lb.del. lactis & Lb.del. lactis & N.T. \\
\hline 137FR & Lb.acidophilus & Lb.del. lactis & Lb.del. lactis & N.T. \\
\hline $185 \mathrm{FR}$ & $\begin{array}{l}\text { Lb.del. delbrueckii } \\
\text { Lb.acidophilus }\end{array}$ & Lb.del. lactis & Lb.del. lactis & N.T. \\
\hline $270 \mathrm{~N}$ & Lb.del. lactis & Lb.del. lactis & Lb.del. lactis & N.T. \\
\hline $416 \mathrm{~N}$ & $\begin{array}{l}\text { Lb.del. bulgaricus } \\
\text { Lb.del. lactis }\end{array}$ & Lb.del. lactis & Lb.del. lactis & N.T. \\
\hline
\end{tabular}




\begin{tabular}{|c|c|c|c|c|}
\hline Strain & $\begin{array}{c}\text { Strains identified by } \\
\text { API }\end{array}$ & $\begin{array}{c}\text { Strains identified by } \\
\text { SDS-PAGE }\end{array}$ & $\begin{array}{c}\text { Strains identified by } \\
\text { rep-PCR }\end{array}$ & $\begin{array}{l}\text { Strains identified by } \\
\text { spectroscopic method }\end{array}$ \\
\hline $1025 \mathrm{RM}$ & $\begin{array}{l}\text { Lb.del. lactis } \\
\text { Lb.del. bulgaricus } \\
\text { Lb.acidophilus }\end{array}$ & Lb.del. lactis & Lb.del. lactis & Lb.plantarum \\
\hline 701RM & $\begin{array}{l}\text { Lb.del. lactis } \\
\text { Lb.acidophilus }\end{array}$ & Lb.del. lactis & Lb.del. lactis & N.T. \\
\hline $511 \mathrm{KC}$ & Lb.del. delbrueckii & Lb.del. lactis & Lb.del. lactis & N.T. \\
\hline $335 \mathrm{~N}$ & $\begin{array}{l}\text { Lb.acidophilus } \\
\text { Lb. del. lactis }\end{array}$ & Lb.del. lactis & Lb.del. lactis & Lb.delbrueckii \\
\hline $260 \mathrm{KC}$ & Lb.fermentum & Lb.fermentum & Lb.fermentum & N.T. \\
\hline $247 \mathrm{KC}$ & Lb.fermentum & Lb.fermentum & Lb.fermentum & $\begin{array}{l}\text { Lb.fermentum } \\
\text { Lb.plantarum } \\
\text { Lb.delbrueckii }\end{array}$ \\
\hline $334 N$ & Lb.fermentum & Lb.fermentum & Lb.fermentum & Lb.fermentum \\
\hline $67 \mathrm{FR}$ & Lb.paracasei & Lb.paracasei & Lb.paracasei & Lb.paracasei \\
\hline $158 \mathrm{FR}$ & Lb.paracasei & Lb.paracasei & Lb.paracasei & Lb.paracasei \\
\hline 190FR & $\begin{array}{l}\text { Lb.paracasei } \\
\text { Lb.rhamnosus }\end{array}$ & Lb.paracasei & Lb.paracasei & Lb.paracasei \\
\hline $393 \mathrm{KC}$ & $\begin{array}{l}\text { Lb.paracasei } \\
\text { Lb.plantarum }\end{array}$ & Lb.paracasei & Lb.paracasei & $\begin{array}{l}\text { Lb.paracasei } \\
\text { Lb.plantarum }\end{array}$ \\
\hline $583 \mathrm{~N}$ & Lb.plantarum & Lb.plantarum & Lb.plantarum & Lb.plantarum \\
\hline $420 \mathrm{KC}$ & $\begin{array}{l}\text { Lb.plantarum } \\
\text { Lb.pentosus }\end{array}$ & Lb.plantarum & Lb.plantarum & Lb.plantarum \\
\hline $404 \mathrm{KC}$ & Lb.plantarum & Lb.plantarum & Lb.plantarum & Lb.plantarum \\
\hline $446 \mathrm{KC}$ & Lb.plantarum & Lb.plantarum & Lb.plantarum & Lb.plantarum \\
\hline $284 \mathrm{KC}$ & $\begin{array}{l}\text { Lb.plantarum } \\
\text { Lb.pentosus }\end{array}$ & Lb.plantarum & Lb.plantarum & Lb.plantarum \\
\hline $481 \mathrm{KC}$ & Lb.plantarum & Lb.plantarum & Lb.plantarum & Lb.plantarum \\
\hline $475 \mathrm{KC}$ & Lb.plantarum & Lb.plantarum & Lb.plantarum & Lb.plantarum \\
\hline $586 \mathrm{~N}$ & Lb.plantarum & Lb.plantarum & Lb.plantarum & N.T. \\
\hline $493 \mathrm{KC}$ & Lb.plantarum & Lb.plantarum & Lb.plantarum & Lb.plantarum \\
\hline $432 \mathrm{KC}$ & Lb.plantarum & Lb.plantarum & Lb.plantarum & N.T. \\
\hline $257 \mathrm{KC}$ & $\begin{array}{l}\text { Lb.pentosus } \\
\text { Lb.plantarum }\end{array}$ & Lb.plantarum & Lb.plantarum & Lb.plantarum \\
\hline $286 \mathrm{KC}$ & $\begin{array}{l}\text { Lb.pentosus } \\
\text { Lb.plantarum }\end{array}$ & Lb.plantarum & Lb.plantarum & Lb.paracasei \\
\hline $340 \mathrm{KC}$ & Lb.plantarum & Lb.plantarum & Lb.plantarum & Lb.plantarum \\
\hline $662 \mathrm{~N}$ & Lb.plantarum & Lb.plantarum & Lb.plantarum & Lb.plantarum \\
\hline $326 \mathrm{KC}$ & Lb.plantarum & Lb.plantarum & Lb.plantarum & Lb.plantarum \\
\hline $277 \mathrm{KC}$ & $\begin{array}{l}\text { Lb.plantarum } \\
\text { Lb.paracasei }\end{array}$ & Lb.plantarum & Lb.plantarum & Lb.plantarum \\
\hline $542 \mathrm{RM}$ & $\begin{array}{l}\text { Lb.pentosus } \\
\text { Lb.plantarum }\end{array}$ & Lb.plantarum & Lb.plantarum & Lb.plantarum \\
\hline $832 \mathrm{RM}$ & $\begin{array}{l}\text { Lb.pentosus } \\
\text { Lb.plantarum }\end{array}$ & Lb.plantarum & Lb.plantarum & Lb.plantarum \\
\hline
\end{tabular}

N.T: not tested 


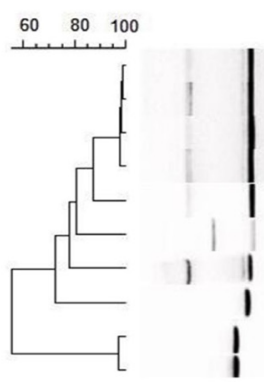

$722 \mathrm{~N}$
$725 \mathrm{~N}$
$702 \mathrm{~N}$
$726 \mathrm{~N}$
$497 \mathrm{~N}$
$572 \mathrm{~N}$
$610 \mathrm{~N}$
$635 \mathrm{~N}$
$722 \mathrm{RM}$
ES0036

Lactobacillus Lactobacillus del bulgaricus Lactobacillus del. hulgaricus Lactobacillus del. bulgaricus Lactobacillus del. bulgaricus Lactobacillus del. bulgaricus Lactobacillus del. bulgaricus Lactobacillus del. bulgaricus Lactobacillus del. bulgaricus Lactobacillus del. bulgaricus

C

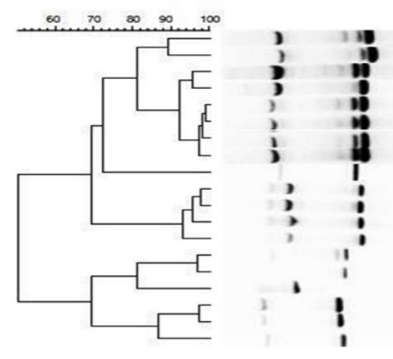

260KC Lactobacillus fermentum

$334 \mathrm{~N} \quad$ Lactobacillus fermentum 9LMB Lactobacillus fermentum 247KC Lactobacillus fermentum

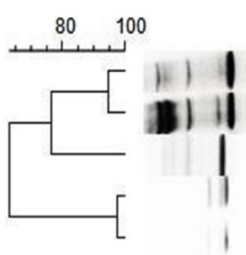

Lactobacillus paracasei paracasei Lactobacillus paracasei paracasei Lactobacillus paracasei paracasei Lactobacillus paracasei paracasei Lactobacillus paracasei paracasei
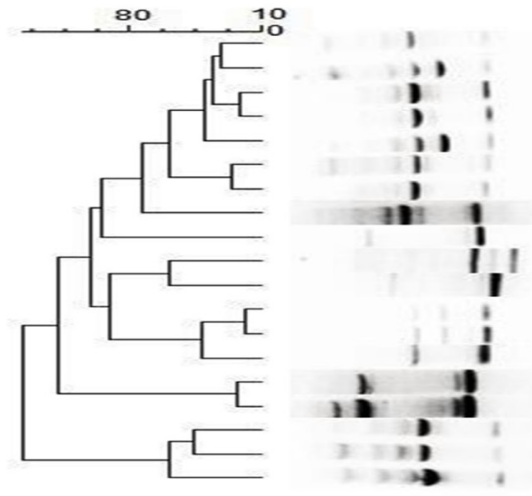

$326 K C$
$277 K C$
$662 N$
CNRZ
$257 K C$
$284 K C$
$446 K C$
$481 K C$
$340 K C$
$286 K C$
$583 N$
$432 K C$
$475 K C$
$542 R M$
$404 K C$
$832 R M$
$420 K C$
$493 K C$
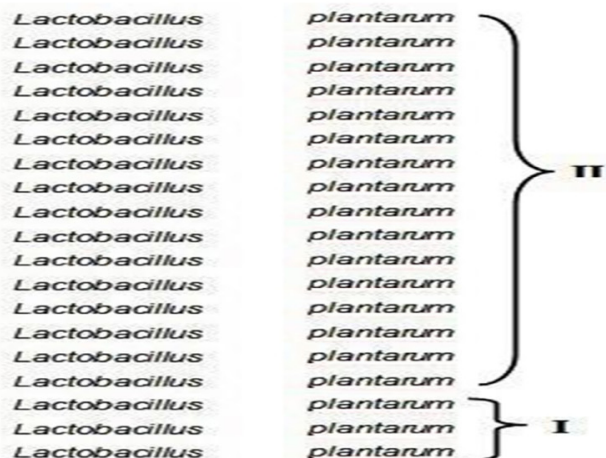

Fig. 1: Dendrogram generated from BOX-PCR fingerprints of lactobacilli strains: (A) Lactobacillus delbrueckii subsp. bulgaricus, (B) Lactobacillus delbrueckii subsp. lactis, Lactobacillus fermentum (C), Lactobacillus paracasei subsp. paracasei (D) and (E) Lactobacillus plantarum. The dendogram was constructed using the unweighted pair group method using arithmetic mean, with correlation levels expressed as percentages

Lb. del. bulgaricus ES0036, Lb. del. lactis CNRZ245, Lb. fermentum 9LMB, Lb. paracasei paracasei 2ROM and $L$ b. plantarum CNRZ739 are reference strains. 
F2) explained $99.91 \%$ of total variance. The four groups were perfectly separated, and the analyses revealed the close relatedness of $L b$. delbrueckii subsp. bulgaricus and Lb. delbrueckii subsp. lactis. Cross-validation results from the FDA confusion matrix showed $100 \%$ correct classification.

In a second step, a similar analysis was performed on the spectral data collected from all isolates and reference strains included in this part of the study.

To perform FDA analysis, the groups were created on the basis of phenotypic and molecular based-results. The seven groups were $\mathrm{Lb}$. delbrueckii subsp. bulgaricus and Lb. delbrueckii subsp. lactis (isolates and reference strains), $L b$. fermentum, Lb. paracasei subsp paracasei (isolates and reference strains) and $L b$. plantarum (isolates and reference strains). On the factorial map (Fig. 2) corresponding to this FDA, the first two discriminant factors (F1 and F2) explained $65.69 \%$ of total variance and allowed the differentiation of seven distinct groups, despite the dispersion of a few spectra. $L b$. fermentum strains were well separated from other strains according to factor F2, which accounted for $29.87 \%$ of total variance. On this axis, $L b$ paracase $i$ were also well separated from Lb. delbrueckii subsp. lactis and bulgaricus. Note that the method failed to discriminate these latter two subspecies. According to factor F1 which ac- counted for $35,82 \%$ of total variance, $L b$. paracasei subsp. paracasei was clearly distinct from $L b$. plantarum but close to Lb. fermentum.

The cross-validation analysis was managed by poling Lb. delbrueckii subsp. lactis and Lb. delbrueckii subsp. bulgaricuss into a species group. Percent correct classification varied from $66.67 \%$ for $L b$. plantarum to $100 \%$ for Lb. delbrueckii, $L b$. paracasei subsp. paracasei and Lb. plantarum reference strains. The model attributed one $L b$. plantarum $286 \mathrm{KC}$ strain to $L$ b paracasei, while two strains of Lb. delbrueckii subsp. lactis (1025RM and $217 \mathrm{~N}$ ) were reclassified as Lb. plantarum (Tables 1 and 2).

Synchronous fluorescence spectroscopy is a fast, simple and low-cost reagent less tool for studying strain relatedness, and can be considered a reliable way to study the bacterial taxonomy of complex clades such as Lactobacilli.

\section{CONCLUSION}

From this investigation, phenotypic, genomic and spectroscopic methods have been combined and compared to identify wild-type lactic acid bacteria isolated from traditional dairy products and preliminarily identified as Lactobacillus. The 52 isolates studied belonged to the species delbrueckii, (subsp. lactis, bulgaricus), plantarum, paracasei and fermentum.

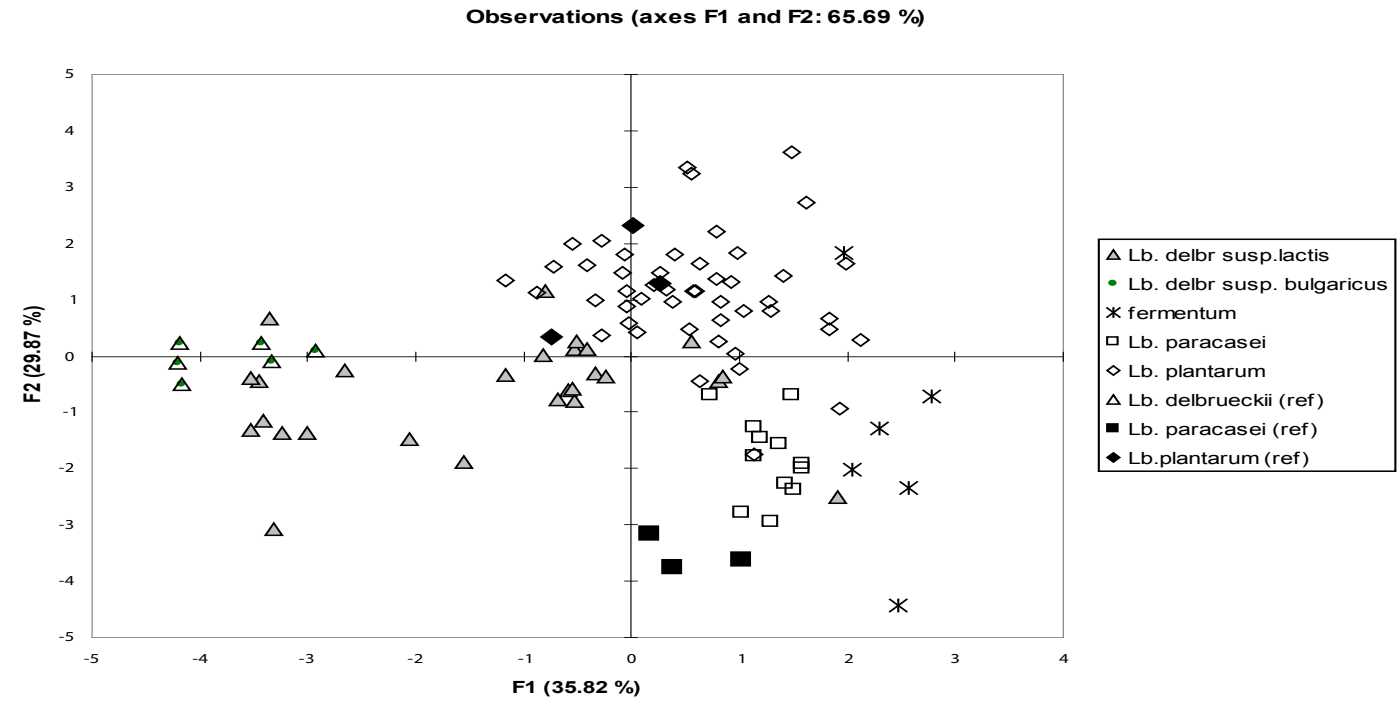

Fig. 2: Discriminant analysis similarity map determined by discriminant factors $F 1$ and $F 2$ for the synchronous fluorescence $(\Delta \lambda=\mathbf{3 0} \mathrm{nm})$ spectral data of lactobacilli

(ref: reference strains) 
Table 2: Percentage of correct classification according to the confusion matrix resulting from FDA analysis performed on the synchronous spectra collected from lactobacilli isolates and reference strains

\begin{tabular}{|c|c|c|c|c|c|c|c|c|c|}
\hline from $\backslash$ to & delb & delb & fermentum & paracasei & paracasei & plantarum & plantarum & Total & $\%$ correct \\
\hline Lb. delbrueckii & 19 & 3 & 1 & 0 & 0 & 4 & 0 & 27 & 70.37 \\
\hline Lb.delbrueckii ${ }^{\mathrm{R}}$ & 0 & 6 & 0 & 0 & 0 & 0 & 0 & 6 & 100.00 \\
\hline Lb.fermentum & 1 & 0 & 4 & 0 & 0 & 1 & 0 & 6 & 66.67 \\
\hline Lb.paracasei & 0 & 0 & 0 & 11 & 0 & 1 & 0 & 12 & 91.67 \\
\hline Lb.paracasei ${ }^{\mathrm{R}}$ & 0 & 0 & 0 & 0 & 3 & 0 & 0 & 3 & 100.00 \\
\hline Lb.plantarum & 0 & 0 & 0 & 2 & 0 & 45 & 1 & 48 & 93.75 \\
\hline Lb.plantarum ${ }^{\mathrm{R}}$ & 0 & 0 & 0 & 0 & 0 & 0 & 3 & 3 & 100.00 \\
\hline Total & 20 & 9 & 5 & 13 & 3 & 51 & 4 & 105 & 86.67 \\
\hline
\end{tabular}

R: reference strains

Discrimination of the isolates at species level was excellent using SDS-PAGE rep-PCR and spectroscopic analysis, which revealed a close relatedness of $L b$. paracasei subsp. paracase $i$ and $L b$. fermentum isolates that had not been described for the reference strains, suggesting an ecological adaptation revealed by whole-cell component analysis.

Rep-PCR based on Boxair primers and fluorescence-based spectroscopy was able to differentiate species and subspecies, even for the two Lactobacillus delbrueckii subspecies which form a fairly heterogenic taxon from a metabolic point of view but are barely distinguishable by genomic studies such as $16 \mathrm{~S}$ rDNA sequence comparison (Canchaya et al., 2006). It was able to identify isolates that the API system had failed to assign to a defined taxonomic position (Table 1).

Working with colonies on agar plates, rep-PCR analysis is fairly straightforward but still requires several steps, toxic reagents, and primers. In contrast, optical fiber-based synchronous fluorescence spectroscopy of colonies on agar plates requires no manual preparation of the cells and no reagents, and spectra are obtained within just a few minutes. Suitable chemometric treatments make it easy to study strain relatedness. This study yields very encouraging results for Lactobacillus isolates, although further investigations are needed since there was no reliable way to analyze transparent colonies. For rapid isolate identification, the investigation hinges on access to robust databases that include as many reference and wild-type strains as possible. This investigation is work in progress. Nevertheless, this tool has already proven its reliability for other taxons (Tourkya et al., 2011 , in press) and should be rapidly integrated into the panel of techniques for a polyphasic approach to lactic acid bacteria taxonomy.

\section{ACKNOWLEDGEMENTS}

The authors thank the Academy of Scientific Research and Technology (IMHOTEP program) for funding the project. We also thank Mariam Mohammed and Ali El Komi for providing valuable technical assistance.

\section{REFERENCES}

Allen, T.G., 1936. Egyptian Stelae in field museum of natural history, Chicago: Field museum of natural history: anthropological series (XXIV)-1.

Amiel, C., Mariey, L., Curk-Daubié, M.C., Pichon, P. \& Travert, J. 2000. Potentiality of Fourier transform infrared spectroscopy (FTIR) for discrimination and identification of dairy lactic acid bacteria. Le Lait, 80: 445-459.

Ammor, M. 2007. Recent advances in the use of intrinsic fluorescence for bacterial identification and characterization. Journal of Fluorescence, 17: 455-459.

Bernardeau, M., Vernoux J. P., Henri-Dubernet, S., \& Guéguen, M. 2008. Safety assessment of dairy microorganisms: The Lactobacillus genus. International Journal of Food Microbiology, 126: 278285.

Bertrand, D., \& Scotter, C.N.G. 1992. Application of multivariate analyses to NIR spectra of gelatinized starch. Applied Spectroscopy, 46: 1420- 1425.

Bertrand, D., Courcoux, P., \& Qannari, E.M. 2006. Méthodes exploratoires. In: La Spectroscopie Infrarouge et ses Applications Analytiques. D. Bertrand, \& E. Dufour (Eds). Lavoisier Paris, pp 317-345.

Berthier, F., \& Ehrlich, S.D. 1998. Rapid species identification within two groups of closely related lactobacilli using PCR primers that target the $16 \mathrm{~S} / 23 \mathrm{~S}$ 
rRNA space region. FEMS Microbiology Letters, 161: $97-106$.

Bhatta, H., Goldys, E.M., \& Learmonth, R.P. 2006. Use of fluorescence spectroscopy to differentiate yeast and bacterial cells. Applied Microbiology and Biotechnology, 71: 121-126.

Bosch, A., Golowczyc, M.A., Abraham, A.G., Garrote, G.L., De Antoni, G.L., \& Yantorno, O. 2006. Rapid discrimination of lactobacilli isolated from kefir grains by FT-IR spectroscopy. International Journal of Food Microbiology, 111: 280-287.

Boyd, M. A., Antonio M. A., \& Hillier, S.L. 2005. Comparison of API $50 \mathrm{CH}$ strips to whole-chromosomal DNA probes for identification of Lactobacillus species. Journal of Clinical Microbiology, 43: 5309-5311.

Canchaya, C., Claesson M. J., Fitzgerald, G. F., Van Sinderen D., \& O'Toole, P.W. 2006. Diversity of the genus Lactobacillus revealed by comparative genomics of five species. Microbiology, 152: 31853196.

Cantor, C.R., \& Schimmel, P.R. 1980. Other optical techniques. In: Biophysical Chemistry-part 2: Techniques for the Study of Biological Structure and Function. Freeman, W.H. \& Cie (Eds.), New York, pp 409-480.

Coeuret, V., Dubernet, S., Bernardeau, M., Gueguen, M., \& Vernoux, J.P. 2003. Isolation, characterization and identification of lactobacilli focusing mainly on cheeses and other dairy products. Le Lait, $\mathbf{8 3}$ : 269-306.

Delfederico, L., Hollmann, A., Martínez, M., Iglesias, N.G., De Antoni, G., \& Semorile, L. 2006. Molecular identification and typing of lactobacilli isolated from kefir grains. Journal of Dairy Research, 73: 20-27.

Dziuba, B., Babuchowski, A., Nalecz, D., \& Niklewicz, M. 2007. Identification of lactic acid bacteria using FTIR spectroscopy and cluster analysis. International Dairy Journal, 17: 183-189.

El Soda, M., Ahmed, N., Omran, N., Osman, G., \& Morsi, A. 2003. Isolation, identification and selection of lactic acid bacteria cultures for cheesemaking. Emirate Journal of Agriculture Science, 15: 5171

EFSA, 2010. Scientific opinion on the maintenance of the list of QPS biological agents intentionally added to food and feed, Request EFSA-Q-2010-00086. The European Food Safety Authority Journal, 8: 56.

Estes, C., Duncan, A., Wade, B., Lloyd, C., Ellis, W., \& Power, L. 2003. Reagentless detection of micro- organisms by intrinsic fluorescence. Biosensors and Bioelectronics, 18: 511-519.

Gaus, K., Rösch, P., Petry, R., Peschke, K.-D., Ronneberger, O., Burkhardt, H., Baumann, K., \& Popp, J. 2006. Classification of lactic acid bacteria with UV-resonance Raman spectroscopy.Biopolymers, 82: $286-90$

Gevers D., Huys G., \& Swings, J. 2001. Applicability of rep-PCR fingerprinting for identification of Lactobacillus species. FEMS Microbiology Letters, 205: 31-36.

Jolliffe, I.T. 1986. Principal Component Analysis. Springer, New York, pp. 271.

Kohavi, R. 1995. A study of cross-validation and bootstrap for accuracy estimation and model selection. Proceedings of the Fourteenth International Joint Conference on Artificial Intelligence, 2: 1137-1143.

Lakowicz, J.R. 1999. Principles of Fluorescence Spectroscopy. $2^{\text {nd }}$ ed. Kluwer Academic/Plenum, New York, pp 341-389.

Leblanc, L., \& Dufour, E. 2002. Monitoring the identity of bacteria using their intrinsic fluorescence. FEMS Microbiology Letters, 211: $147-153$

Leriche, F., Bordessoules, A., Fayolle, K., Karoui, R., Laval, K., Leblanc, L. \& Dufour, E. 2004. Alteration of raw-milk cheese by Pseudomonas spp. monitoring the sources of contamination using fluorescence spectroscopy and metabolic profiling. Journal of Microbiological Methods, 59: 33-41.

Mariey, L., Signolle, J.P., Amiel, C., \& Travert, J. 2001. Discrimination, classification, identification of microorganisms using FTIR spectroscopy and chemometrics. Vibrational Spectroscopy, 26: 151-159.,

Mohammed, M., Abd El-Aziz, H., Omran, N., Anwar, S., Awad, S., \& El-Soda, M. 2009. RepPCR characterization and biochemical selection of lactic acid bacteria isolated from the Delta area of Egypt. International Journal of Food Microbiology, 128: 417-423.

Montel, M.C., Talon, R., Fournaud, J., \& Champommier, M.C. 1991. A simplified key for identifying homofermentative Lactobacillus and Carnobacterium spp. from meat. Journal of Applied Bacteriology, 70: 469-472.

Naser, S.M., Dawyndt P., Hoste B., Gevers D., Vandemeulebroecke K., Cleenwerck I., Van- 
canneyt, M., \& Swings, J. 2007. Identification of lactobacilli by pheS and rpoA gene sequence analyses. International Journal of Systematic and Evolutionary Microbiology, 57: 2777-2789.

Pot. B., Vandamme, P., \& Kersters, K. 1994. Analysis of electrophoretic whole-organism protein fingerprints. In: Modern Microbial Methods. Chemical Methods in Prokaryotic Systematics, Goodfellow M., O’Donnell A.G. (Eds.), John Wiley \& Sons Ltd, Chichester, USA, pp 493-521.

Postnikova, E., Baldwin, C., Whitehouse, C.A., Sechler, A., Schaad, N.W., Sampath, R., Harpin, V., Li, F., Melton, R., Blyn, L., Drader, J., Hofstadler, S., \& Schneider, W.L. 2008. Identification of bacterial plant pathogens using multilocus polymerase chain reaction/ electrospray ionization-mass spectrometry. Phytopathology, 98: 1156-1164.

Sánchez, I., Seseña, S. \& Palop, L. 2004. Polyphasic study of the genetic diversity of lactobacilli associated with 'Almagro' eggplants spontaneous fermentation, based on combined numerical analysis of randomly amplified polymorphic DNA and pulsed-field gel electrophoresis patterns. Journal of Applied Microbiology, 97: 446-458.

Sauer, S., \& Kliem, M. 2010. Mass spectrometry tools for the classification and identification of bacteria. Nature Reviews Microbiology, 8 : 74-82.

Savi, D., Jokovi, N., \& Topisirovi, L. 2008. Multivariate statistical methods for discrimination of lactobacilli based on their FTIR spectra. Dairy Science and Technology, 88: 273-290.

Sharpe, M.E. 1979. Identification of lactic acid bacte- ria. In: Identification Methods for Microbiologists, Skinner FA, \& Lovelock DW (Eds.), London: Academic Press, pp 233-259.

Tailliez, P., Beaud, D., \& Ogier, C. 2002. Le point sur les outils moléculaires de classification et d'écologie microbienne. Science Alimentaire, 22: 5-21.

Temmerman, R., Huys, G., \& Swings, J. 2004. Identification of lactic acid bacteria: culturedependent and culture-independent methods. Trends in Food Science and Technology, 15: 348-359.

Tourkya, B., Boubellouta, T., Dufour, E., \& Leriche, F. 2009. Fluorescence spectroscopy as a promising tool for a polyphasic approach to Pseudomonad taxonomy. Current Microbiology, 58: 39-46.

Tourkya B., Karoui R., Berdague J.L., Boubellouta T., Dufour E., \& Leriche, F. 2011. Optical fiber-based synchronous fluorescence spectroscopy for bacterial discrimination directly from colonies on agar plates. Analytical Methods doi: 10.1039/C0AY00135J

Vandamme, P., Pot, B., Gillis M., De Vos P., Kersters K., \& Swings, J. 1996. Polyphasic taxonomy, a consensus approach to bacterial systematics. Microbiological Reviews, 60: 407-438.

Wijtzes, T., Bruggeman, M. R., Nout, M. J. R., \& Zwietering, M.H. 1997. A computerised system for the identification of lactic acid bacteria. International Journal of Food Microbiology, 38: 65-70.

Wittrup C, 2000. Comparison of chemometric methods for classification of fungal extracts based on rapid fluorescence spectroscopy. Journal of Chemometrics, 14: 765-776. 


\section{طرق التعرف المتعلدة لسلالات من الالاكتوبسيلس : مقارنة مابيز الطرق المظهرية والورواثية والسبكتروسكوبية الماتهوبية \\ عيشة العطار (1)، بلال تركيا(r)، فرانسواز لوريش(r)، مرسي السودة(1)

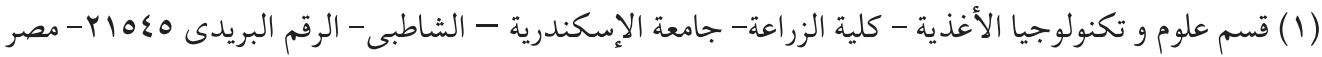

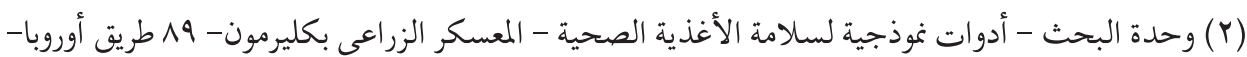 لامبد- فرنسا}

تشكل البكتريات العصوية مجموعة كبيرة ومتنوعة من بكتيريا حمض اللاكتيك. في اللبن الخام ومنتجات الألبان

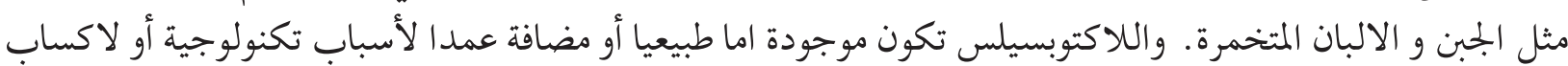

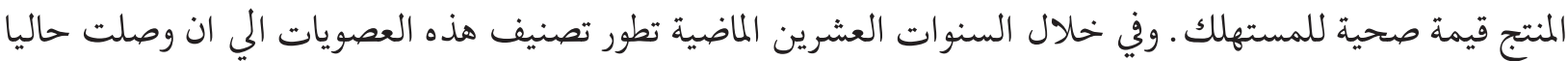
الي أكثر من · الم النوعا.

تم استخدام كل من الـ 50APICH (جهاز وإجراءات التعرف علي البكتريا)، طريقة الهجرة الكهربية SDS-PAGE

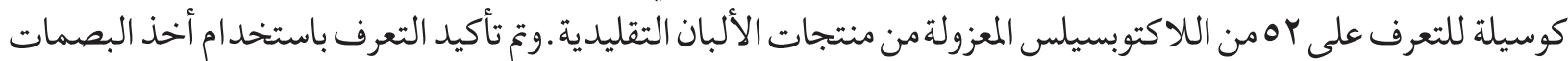

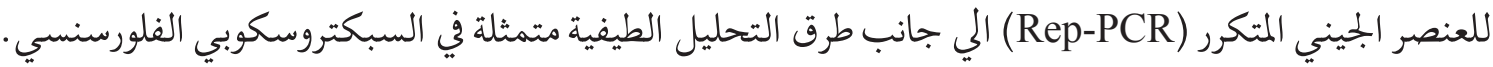

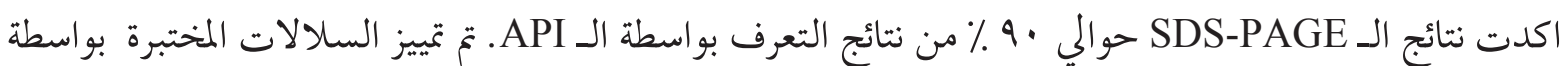

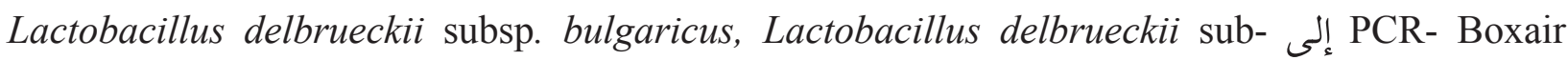
sp. lactis, Lactobacillus fermentum, Lactobacillus paracasei subsp. paracasei, Lactobacillus

.plantarum

وتم تأكيد كل نتائج SDS-PAGE المظهرية بواسطة الطريقة الوراثية. ولقد تم تسجيل متزامن للأطياف الفلورنسيية SyFS

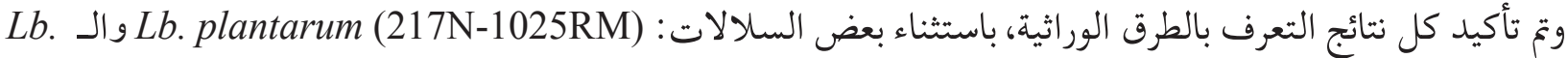

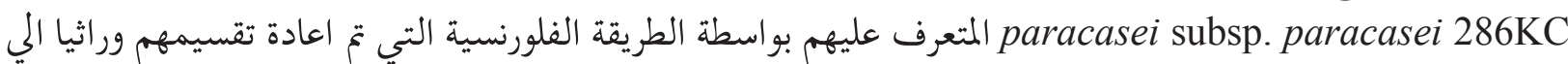
. Lb. delbrueckii subsp. lactis و Lb. plantarum تسلط هذه الدراسة الضوء علي توفير البيانات الطيفية كبصمات مظهرية حقيقية للبكتيريا وبالتالي يمكن استخدامها

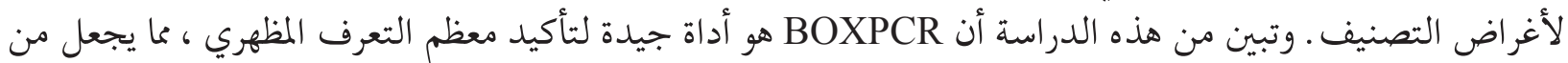

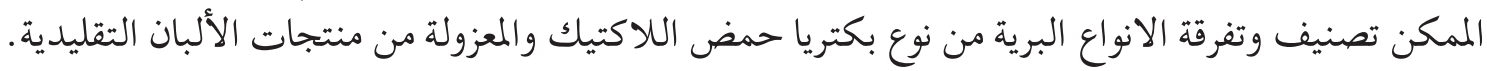

